\title{
Stable carbon isotopes of wood: a clue to palaeoclimate?
}

\author{
Pim F. van Bergen ${ }^{\mathrm{a}, *}$, Imogen Poole ${ }^{\mathrm{b}}$ \\ a Geochemistry, Faculty of Earth Sciences, Utrecht University, P.O. Box 80021, 3508 TA Utrecht, The Netherlands \\ b School of Earth Sciences, University of Leeds, Leeds LS2 9JT, UK
}

\begin{abstract}
Detailed stable carbon isotope and molecular investigations were undertaken on a number of archaeological and fossil wood specimens to provide insights into their use as rigorous independent palaeoclimatic and palaeoenvironmental parameters. The isotope data revealed large differences amongst the material with the oldest specimens being least depleted in ${ }^{13} \mathrm{C}$. Although natural variation could account for some of the observed differences, the isotope values of the archaeological and Tertiary specimens are most probably related to the absolute abundance of polysaccharides present and the degree of lignin alteration. The molecular data, based on pyrolysis, of the Antarctic Cretaceous conifer specimens revealed only transformed lignin, with virtually no intact lignin building blocks (2methoxyphenols) preserved, and no evidence of polysaccharides. This degree of chemical alteration is suggested here to be one of the main causes for the ${ }^{13} \mathrm{C}$ enriched values of these conifer specimens. These results show the importance of combining detailed molecular information on individual wood components with stable carbon isotope data for palaeoclimatic and palaeoenvironmental studies. (C) 2002 Elsevier Science B.V. All rights reserved.
\end{abstract}

Keywords: stable carbon isotopes; pyrolysis; fossil wood; palaeoclimate; lignin; cellulose

\section{Introduction}

Fossil plant remains, i.e., leaves, propagules, wood, pollen and spores, are being used extensively to provide detailed information on environmental and climatic conditions in the past (e.g., Jones and Rowe, 1999). Many of these interpretations are based on the recognition and identification of a fossil to a certain taxonomic level. Subsequently, comparisons with modern-day equivalents can then provide valuable information pertaining to the environment and climate in which these plants grew (e.g., Mosbrugger,

\footnotetext{
* Corresponding author. Tel.: +31-30-2535105; Fax: +31-30-2535030.

E-mail address: p.vanbergen@geo.uu.nl (P.F. van Bergen).
}

1999). An alternative approach is to use morphological and anatomical characters, i.e., stomatal characteristics (e.g., van der Burgh et al., 1993; Kürschner et al., 1996; Poole et al., 1996; Beerling and Woodward, 1996) or specific wood characters (e.g., Wheeler and Baas, 1993; Wiemann et al., 1998, 1999) that reflect certain environmental conditions.

Apart from influencing visible characters, changes in climate and environment can also affect the chemical composition of a plant. However, only in recent years have studies of the detailed chemical composition of organic fossil plant remains been gathering momentum (e.g., Boon et al., 1989; van Bergen et al., 1995a). For example, information regarding the environment of deposition (e.g., aerobic or anaerobic) can be obtained from the chemical alterations of original biomol- 
ecules. Another chemical character currently in use is the ratio of ${ }^{13} \mathrm{C}$ and ${ }^{12} \mathrm{C}$ preserved in organic plant remains (e.g., for a recent overview see Gröcke, 1998).

The basic underlying rationale for the use of these stable carbon isotopes in plants lies in the fact that during photosynthesis a large kinetic fractionation effect occurs favouring ${ }^{12} \mathrm{C}$ over ${ }^{13} \mathrm{C}$ (O'Leary, 1981; Farquhar et al., 1982, 1989). This ratio, expressed as $\delta^{13} C^{1}$, in modern plants depends on a number of factors, the main ones being the photosynthetic pathway used $\left(C_{3}\right.$, $\mathrm{C}_{4}$ or $\mathrm{CAM}$ ), the isotope composition and the concentration of $\mathrm{CO}_{2}$ in the atmosphere. Other parameters, often with a more local effect and less well understood, include salinity, aspect, nutrient availability, temperature and altitude (e.g., Lockheart et al., 1997, 1998; Gröcke, 1998 and references cited therein). Plant organic matter subsequently preserved in the fossil record retains its approximate $\delta^{13} \mathrm{C}$ value (Degens, 1969; Bocherens et al., 1993). Consequently, stable carbon isotope changes recognised in the geological record can be used to provide palaeoenvironmental and/or palaeoclimatic information (Arens et al., 2000).

Initially, most studies used bulk organic matter $(\mathrm{OM})$. However, it is now widely known that bulk $\mathrm{OM}$ is a weighted mean average of different types of organic matter each having its own isotope composition. One possible way to reduce this complexity is to use morphologically well-defined organic plant remains, i.e., fossils. Subsequent comparisons with modern counterparts will allow insight into the original molecular composition and into the level of chemical alteration, both of which determine the actual stable carbon isotope composition of the fossil. To date, stable carbon isotope studies using fossils have mainly concentrated on leaf (e.g., Bocherens et al., 1993; Huang et al., 1995, 1996; Beerling et al., 1993; Lockheart, 1997; Nguyen Tu et al., 1999; Arens and Jahren, 2000) and some wood material (e.g., Spiker and Hatcher, 1987; Bates and Spiker,

${ }^{1} \delta^{13} \mathrm{C} \% o=\left[\left({ }^{13} \mathrm{C} /{ }^{12} \mathrm{C}_{\text {sample }}\right) /\left({ }^{13} \mathrm{C} /{ }^{12} \mathrm{C}_{\text {standard }}\right)-1\right] \times 1000$ with $\mathrm{PDB}$ as the standard.
1992; Frielingsdorf, 1993; Gröcke, 1998; Lücke et al., 1999; Schleser et al., 1999).

Wood is commonly found in the geological record (from the Devonian onwards) and often preserved as large intact organic entities. In most cases, fossil wood can be identified to a certain taxonomic level which will constrain possible chemosystematic variation. More importantly, from a stable carbon isotope viewpoint, the basic molecular composition of the solvent insoluble component, i.e., ligno-cellulose which constitutes the bulk of wood, is well-known. Ligno-cellulose is composed of polysaccharides, hemicellulose and cellulose, and lignin (Sarkanen and Ludwig, 1971; Lewis and Yamamoto, 1990). The composition of lignin varies according to major plant taxa; gymnosperm lignin is comprised of 2-methoxyphenol moieties (guaiacyl units) whilst angiosperm lignin also contains 2,6-dimethoxyphenol moieties (syringyl units) (Sarkanen and Ludwig, 1971; Lewis and Yamamoto, 1990). The ${ }^{13} \mathrm{C} /{ }^{12} \mathrm{C}$ ratio of these three moieties differs significantly within a specimen with the hemicellulose being least depleted, and lignin being most depleted; e.g., hemicellulose approx. $-23 \%$, cellulose approx. $-25 \%$, lignin approx. $-28 \%$ o (Wilson and Grinsted, 1977; Benner et al., 1987; Spiker and Hatcher, 1987).

Based mainly on bulk and cellulose analyses, it has become evident that changes in atmospheric $\mathrm{CO}_{2}$ concentration and stable carbon isotope composition are recorded in the organic substances of wood (e.g., Craig, 1954; Farmer and Baxter, 1974; Farmer, 1979; Mazany et al., 1980; Tans and Mook, 1980; Francey and Farquhar, 1982; Leavitt and Long, 1982, 1983; Stuiver and Braziunas, 1987). However, carbon isotope heterogeneity in modern wood can be the result of location within the tree, time of wood formation, ligno-cellulose composition, species, temperature, altitude, salinity, humidity (Tans and Mook, 1980; Francey and Farquhar, 1982; Leavitt and Long, 1982, 1983, 1986, 1991; Stuiver and Braziunas, 1987; Schleser, 1992; Lipp et al., 1996; Ogle and McCormac, 1996; Robertson et al., 1996; Bert et al., 1997). Therefore such heterogeneity is a significant aspect that has to be considered prior to interpreting data from historic 


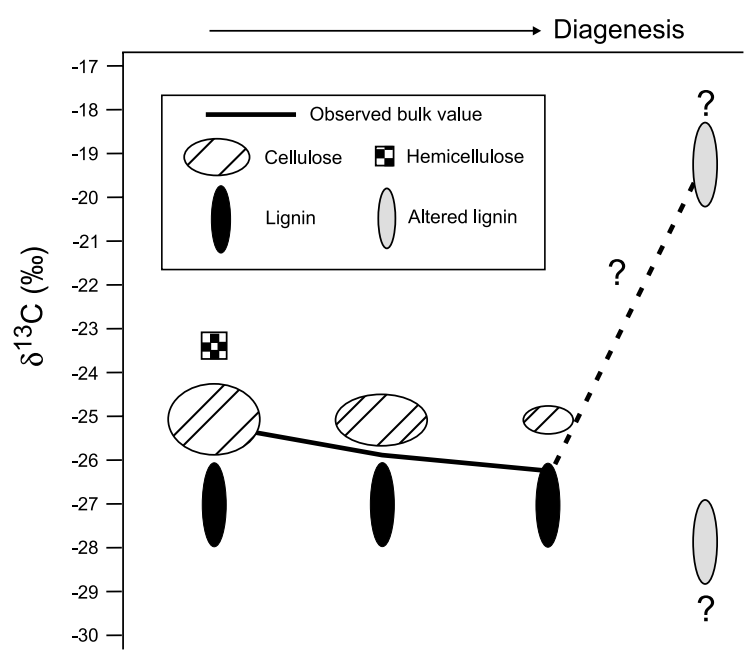

Fig. 1. Schematic representation of how chemical taphonomy can affect the bulk stable carbon isotope signal of fossil wood specimens during diagenesis.

and fossil material. Regarding fossil wood, another important factor that has to be taken into account is chemical taphonomy (Fig. 1). Upon burial and subsequent diagenesis the different organic constituents of wood undergo varying degrees of degradation. It is well known that under natural anaerobic conditions the polysaccharides in wood are preferentially degraded compared with lignin and within the polysaccharide fraction hemicellulose degrades faster than cellulose (e.g., Hedges et al., 1985; Benner et al., 1987). This phenomenon can have a dramatic effect on the bulk stable carbon isotope composition of fossil wood as the removal of polysaccharides results in the material becoming more depleted in ${ }^{13} \mathrm{C}$ (Fig. 1). Finally, the recalcitrant moiety, lignin, also undergoes a certain degree of non-biological chemical transformation such as demethylation and dehydroxylation (Hatcher et al., 1989a,b; van Bergen et al., 1994a, 2000; Hatcher and Clifford, 1997), which may also affect the isotope composition (cf. Schleser et al., 1999 and references cited therein). Thus, if only bulk values were being considered this could in some cases be erroneously construed as a change in atmospheric $\mathrm{CO}_{2}$ composition.

To overcome the problem of chemical heterogeneity, most studies of modern and historic wood material have concentrated on cellulose (e.g., Mazany et al., 1980; Stuiver and Braziunas, 1987; Edwards and Luckman, 1996; Robertson et al., 1996; Switsur et al., 1996). However, in older fossils, viz. Tertiary and Mesozoic specimens, cellulose is often no longer preserved. Consequently, studies have concentrated on isotope data of bulk wood samples (e.g., Gröcke, 1998; Gröcke et al., 1999; Lücke et al., 1999). Moreover, cellulose itself may undergo isotopic changes during diagenesis (Schleser et al., 1999). To date, relatively few stable carbon isotope studies of true fossil wood, excluding coal and maceral samples, have been undertaken (e.g., Spiker and Hatcher, 1987; Bates and Spiker, 1992; Frielingsdorf, 1993; Gröcke, 1998; Lücke et al., 1999; Gröcke et al., 1999; Schleser et al., 1999). Apart from isotope changes in fossil wood apparently related to $\mathrm{CO}_{2}$ composition, variation can also be related to lithology (Gröcke, 1998), which is most probably related to changes in the chemical composition of the wood.

In this paper, case studies using fossils and subfossils from three time slices are used to illustrate this molecular approach. Stable carbon isotope data of anatomically well-defined wood material were combined with detailed molecular information obtained using pyrolysis-gas chromatography-mass spectrometry (Py-GC-MS) in order to investigate the link between the molecular and isotope composition of fossil wood and determine to what extent this can affect palaeoclimatic interpretations.

\section{Material}

A set of two archaeological and 10 fossil wood specimens were used (Table 1). The archaeological specimens were from 50-cm-diameter oak (Quercus), dated as approximately $6000 \mathrm{yr}$, preserved in a shallow marine setting (van Bergen et al., 2000; Whitcombe, 1995). Three specimens of Nothofagus wood (cf. Carlquist, 1987; personal observations), measuring approx. $1.5 \mathrm{~cm}$ in diameter and highly asymmetrical in growth, were obtained from the Sirius Group, Transantarctic Mountains, Antarctica. This material was light brown and mummified, visually distinct from the other specimens studied. Two additional angiosperm and 
three conifer specimens, from the Hambach opencast Miocene brown coal mine were used. These were preserved within an amorphous brown coal matrix. All five specimens from Hambach were approximately $10 \mathrm{~cm}$ wide and $15 \mathrm{~cm}$ long and derived from mature, but of unknown original diameter, wood based on their anatomy (I. Figueiral, personal communication; Figueiral et al., 1999). The final two specimens are branch/trunk material of Cretaceous (Santonin-Campanian) podocarpaceous conifers originating from the Santa Marta Formation, James Ross Island, Antarctica (D.J. Cantrill, personal communication; detailed stratigraphical logs of this area are housed at the B.A.S., Cambridge, UK). All samples showed high-quality anatomical preservation.

\section{Methods}

All specimens were initially cleaned to remove

Table 1

Stable carbon isotope values (\%o versus PDB) of archaeological and fossil wood samples

\begin{tabular}{|c|c|c|c|}
\hline Taxon & Sample & Age & $\begin{array}{l}\delta^{13} C^{c} \\
(\% o)\end{array}$ \\
\hline \multirow{5}{*}{ Quercus sp. ${ }^{\mathrm{a}}$} & 1a & $6000 \mathrm{BP}$ & -26.0 \\
\hline & $1 b$ & & -27.3 \\
\hline & $1 \mathrm{c}$ & & -27.7 \\
\hline & $1 d$ & & -27.7 \\
\hline & $1 \mathrm{e}$ & & -27.5 \\
\hline \multirow{5}{*}{ Quercus sp. ${ }^{\mathrm{a}}$} & $2 \mathrm{a}$ & $6000 \mathrm{BP}$ & -26.5 \\
\hline & $2 b$ & & -26.4 \\
\hline & $2 \mathrm{c}$ & & -25.6 \\
\hline & $2 d$ & & -26.3 \\
\hline & $2 \mathrm{e}$ & & -28.0 \\
\hline \multirow[t]{3}{*}{ Nothofagus sp. ${ }^{\mathrm{b}}$} & no. 8 & Pliocene/Miocene & -23.4 \\
\hline & no. 11 & Pliocene/Miocene & -22.4 \\
\hline & no. 17 & Pliocene/Miocene & -22.4 \\
\hline Taxodium sp. & $\mathrm{R} 2$ & Miocene & -24.9 \\
\hline Picea sp. & S8 & Miocene & -24.2 \\
\hline Sciadopitys sp. & Az1 & Miocene & -23.9 \\
\hline Symplocos sp. & $\mathrm{P} 2$ & Miocene & -26.0 \\
\hline Oleaceae & As1 & Miocene & -25.2 \\
\hline \multirow[t]{3}{*}{ Conifer } & A & Cretaceous & -21.1 \\
\hline & B 1 & Cretaceous & -21.5 \\
\hline & B 2 & Cretaceous & -21.5 \\
\hline
\end{tabular}

\footnotetext{
a a-e: cross-section of logs. a $=$ outside $-\mathrm{e}=$ centre .

b Different specimens from the same formation.

c Accuracy and precision of these measurements are within $0.1 \%$.
}

loose outer material. Samples (several grams) were taken using solvent-cleaned tools. In all cases the material studied contained several growth rings. The archaeological specimens were subsampled from the centre of the wood to the outside, approx. $4 \mathrm{~cm}$ apart, to determine chemical variation related to varying degrees of degradation (i.e., possibly more degraded on the outside). One of the Cretaceous specimens was also subsampled - at approximately $1 \mathrm{~cm}$ apart in transverse section.

Samples were crushed using pestle and mortar and subsequently extracted using ultrasonication [ $3 \times$ dichloromethane $(\mathrm{DCM}), 3 \times \mathrm{DCM} /$ methanol $(\mathrm{MeOH})(1: 1, \mathrm{v}: \mathrm{v}), 3 \times \mathrm{MeOH}]$. After each extraction the material was centrifuged. The supernatant was removed and the residue was dried. All residues, containing the insoluble organic matter representing the bulk of the wood, were stored dry in the dark prior to subjecting them to chemical analyses.

To obtain detailed molecular information, small quantities of powdered sample were examined using on-line flash Py-GC-MS (cf. Stankiewicz et al., 1998). Using this method, insoluble macromolecular organic material can be screened rapidly. Pyrolysis involves cleaving the macromolecular structure into structurally significant fragments (van Bergen, 1999). These are subsequently separated using gas chromatography and identified by mass spectrometry. Using Py-GC-MS on wood samples concomitant information can be obtained concerning the relative abundance of both polysaccharide moieties and lignin (Fig. 2). For example, hemicellulose yields mainly 4-hydroxy-5,6-dihydro-( $2 H$ )-pyran-2-one (HE in Figs. 3 and 4), cellulose will yield levoglucosan (LG in Figs. 3-5) and lignin yields methoxyphenols (G and S labelled compounds in Figs. 3-5). It should be noted, however, that these moieties will also yield numerous additional less specific products (Fig. 3). Amongst the lignin pyrolysis products a further subdivision can be made between 2-methoxyphenols (G-units) and 2,6-dimethoxyphenols (S-units), which are of chemosystematic significance (e.g., gymnosperm versus angiosperm; Saiz-Jimenez and de Leeuw, 1986). For a detailed description of the pyrolysis method used the read- 
Characteristic pyrolysis products from wood

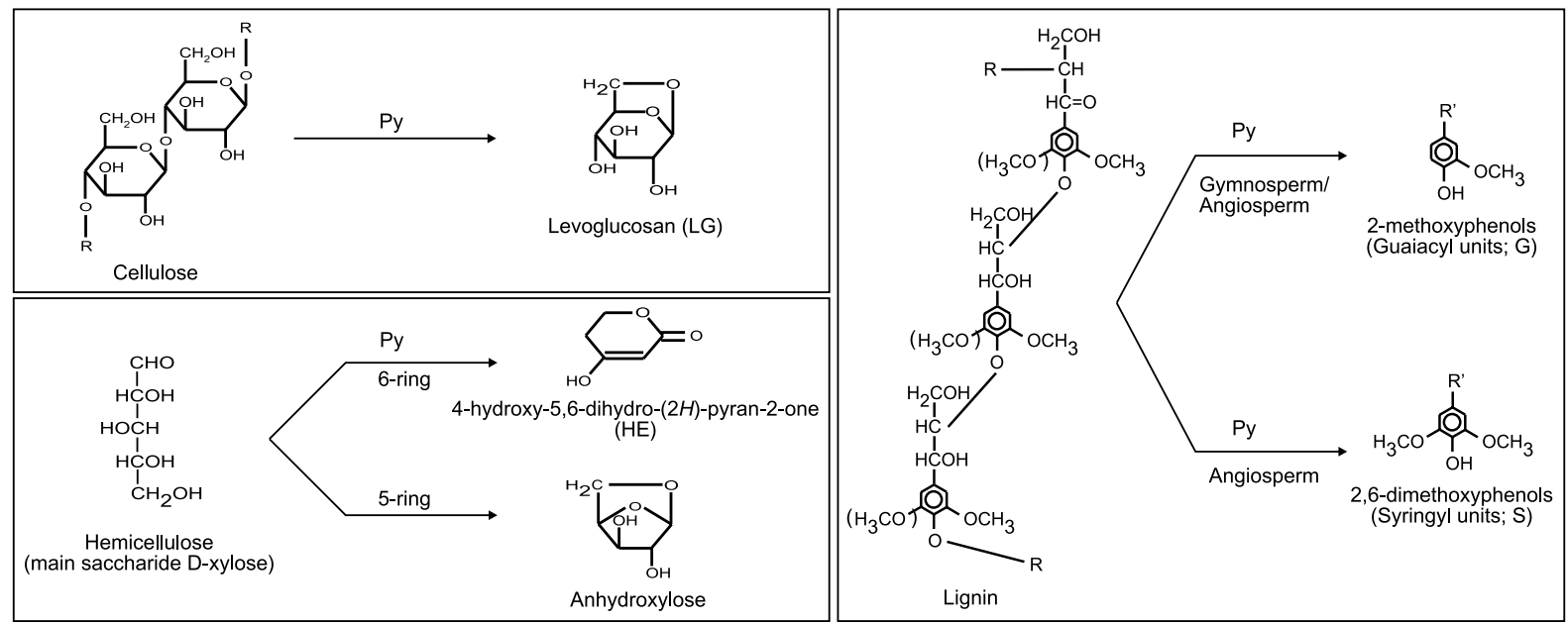

Fig. 2. The main characteristic pyrolysis products released from the three structural moieties of wood (i.e., hemicellulose, cellulose and lignin). Depending on whether xylose occurs as a pyran (6-ring) or furan (5-ring) moiety different products are released. Lignin in gymnosperm is based on 2-methoxyphenol units releasing only 2-methoxyphenol units whilst angiosperm lignin also contains 2,6-dimethoxyphenol units releasing both 2-methoxy- and 2,6-dimethoxyphenols. $\mathrm{R}$ indicates continuation of the macromolecular structure; either glucose units in cellulose or methoxyphenol units in lignin. $\mathrm{R}^{\prime}$ indicates side-chain at carbon atom position number 4 (see side-chains indicated in Figs. 3-7), which vary depending on the lignin structure.

er is referred to van Bergen et al. (2000). Identification of the various pyrolysis products was based on mass spectral data and retention time comparisons with reference samples and data reported in the literature (e.g., Saiz-Jimenez and de Leeuw, 1986; Pouwels et al., 1987, 1989; Ralph and Hatfield, 1991; van Bergen et al., 1996, 2000; Stankiewicz et al., 1997).

On-line bulk stable carbon isotope analyses were performed using a Fisons Instruments NA 1500 elemental analyser (EA) coupled via a ConFlo II interface to a Finnigan MAT Delta Plus isotope ratio mass spectrometer (IRMS). Briefly, approximately $1 \mathrm{mg}$ of sample was weighed into a tin container, sealed and subsequently placed into an AS 200 autosampler connected to the EA. Sealed samples were dropped into a combustion oven held at $1000-1500^{\circ} \mathrm{C}$. Gases produced were flushed through an oxidation reactor $\left(1020^{\circ} \mathrm{C}\right)$ and subsequently over a reduction reactor $\left(650^{\circ} \mathrm{C}\right)$. Water was removed using a water trap and the remaining gas mixture was separated using a chromatographic column. The gases including $\mathrm{CO}_{2}$ were then transferred to the IRMS via the ConFlo II Interface. $\delta^{13} \mathrm{C}$ values of the $\mathrm{CO}_{2}$ were calibrated against reference $\mathrm{CO}_{2}$ (5.0 Airproducts) of known isotope composition, which was introduced directly into the source at the end of each run. All values are based on replicate samples with an accuracy better than $0.1 \%$. The precision of these values, against a laboratory standard that was run before and after each set of samples, was within $0.1 \%$.

\section{Results and discussion}

\subsection{Archaeological specimens}

The $\delta^{13} \mathrm{C}$ values of the archaeological oak wood samples varied between $-25.6 \%$ and $-28.0 \%$ o (Table 1). These values are within the reported $\delta^{13} \mathrm{C}$ values of modern wood from $\mathrm{C}_{3}$ plants; a modern oak wood sample (combined growth rings from 1944-1947) gave a value of $-26.0 \%$. No clear trend reflecting increased degradation and thus enhanced preferential removal of polysaccharides from the wood towards the outside was ob- 


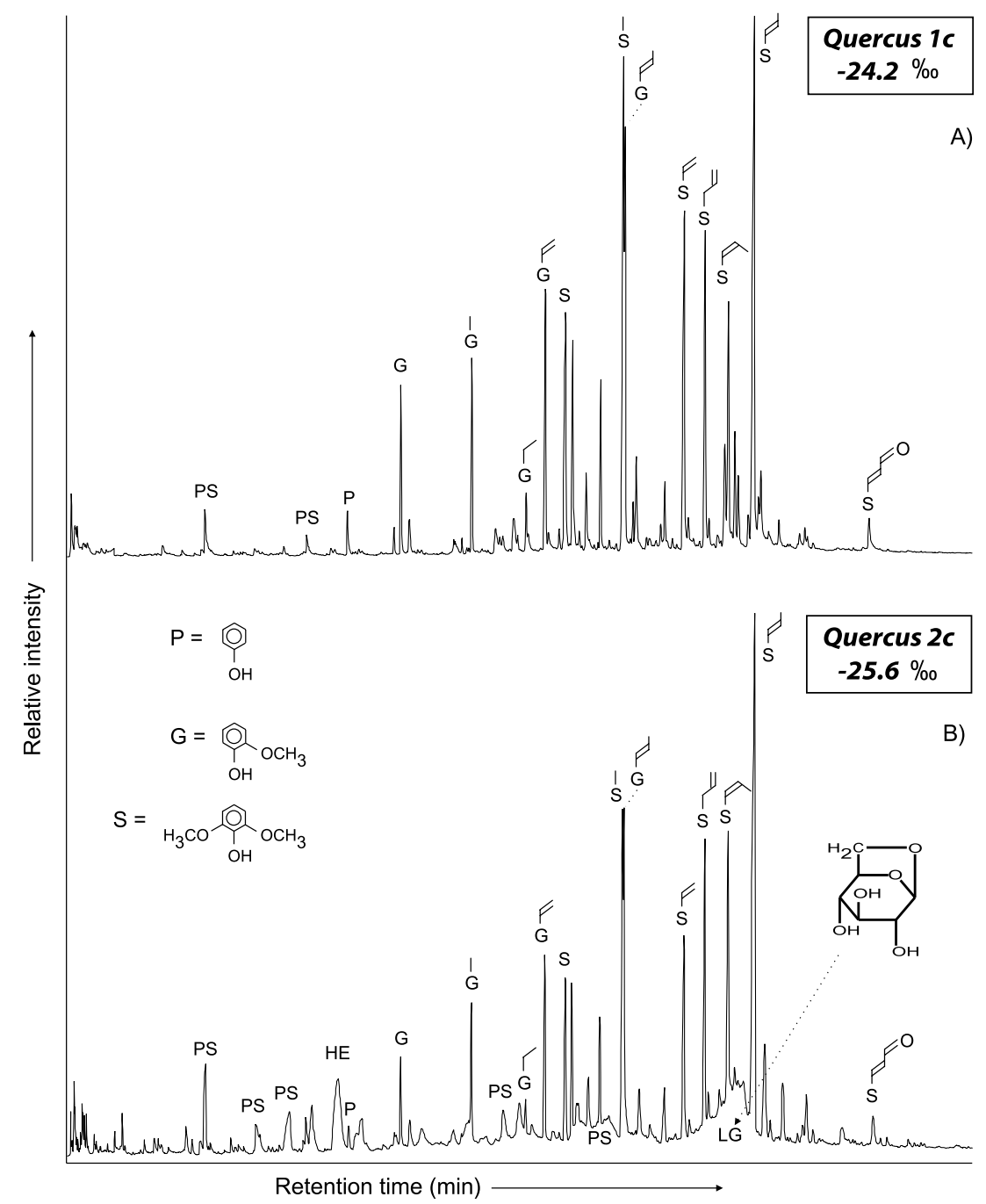

Fig. 3. Total ion currents of on-line flash pyrolysates of archaeological wood samples showing clear evidence of the effect of cellulose contents on their stable carbon isotope composition. PS, polysaccharide pyrolysis products; HE, hemicellulose marker; LG, levoglucosan; G, guaiacyl (2-methoxyphenol) derivatives; S, syringyl (2,6-dimethoxyphenol) derivatives. Side-chains attached at carbon atom 4 are indicated. For further information see Table 1 and Fig. 2.

served. Radial transect variations in $\delta^{13} \mathrm{C}$ values of modern (Wilson and Grinsted, 1977; Mazany et al., 1980; Tans and Mook, 1980) and fossil wood (Bates and Spiker, 1992), due to factors other than selective chemical degradation, have been reported, although such variation was not as great as that found here.

In order to determine the extent to which the polysaccharide contents affected these values, two samples from the middle of the radial transect sampling (samples 1c versus 2c; Table 1) were pyrolysed. The pyrolysate of sample 1c (Fig. 3A) revealed mainly lignin-derived markers ( $G$ and $S$ ) with relatively little evidence of polysaccharide pyrolysis products. In stark contrast, sample 2c (Fig. 3B) revealed numerous polysaccharide markers (PS) including the characteristic cellulose marker, LG, and the hemicellulose marker, HE. 


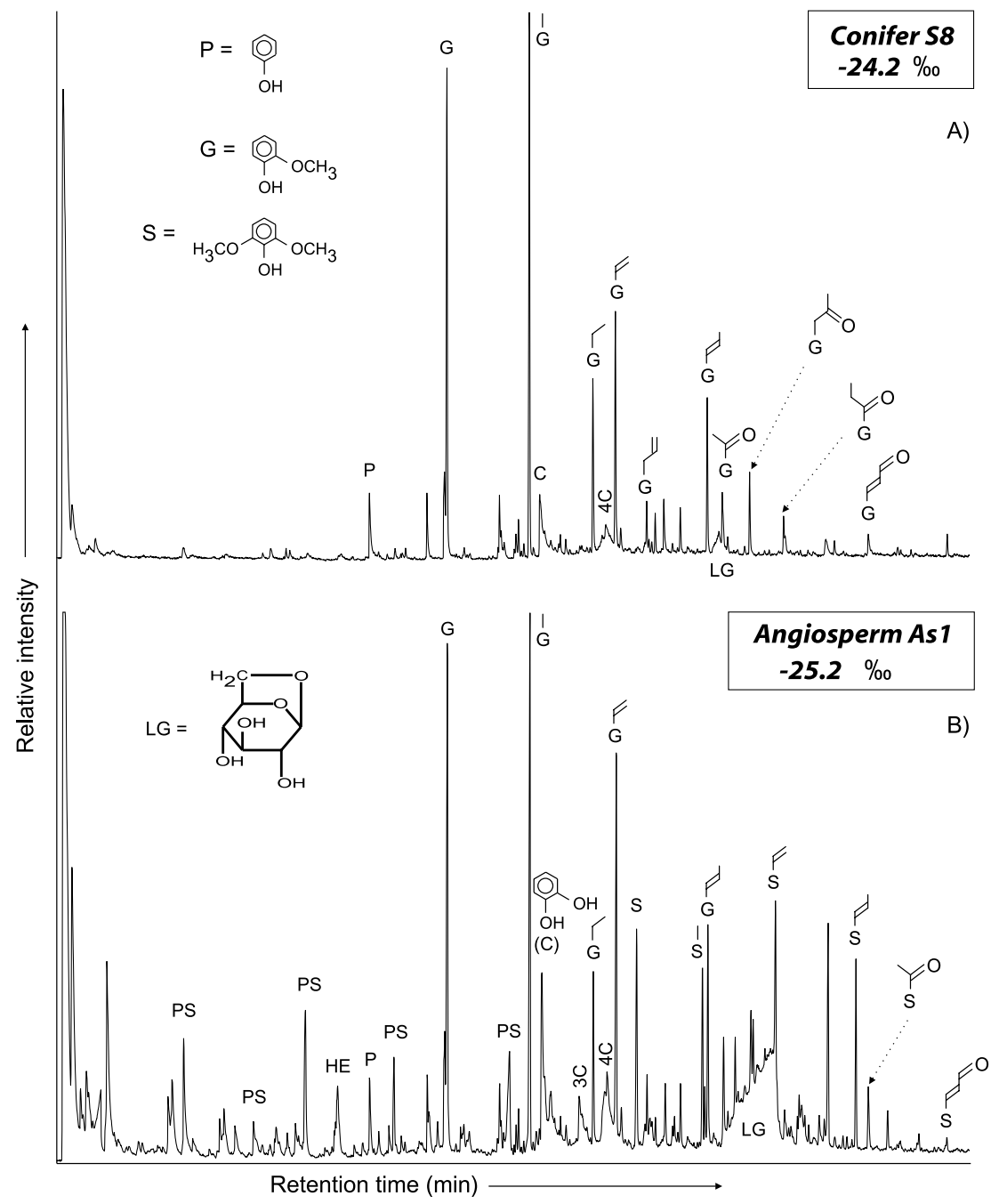

Fig. 4. Total ion currents of on-line flash pyrolysates of Miocene brown coal woods showing the difference in chemical composition between (A) gymnosperms and (B) angiosperms and the difference in polysaccharide contents. C, catechol (1,2-benzenediol); 3C is 3-methyl-1,2-benzenediol; 4C, 4-methyl-1,2-benzenediol; these products are evidence of lignin alteration processes taking place. For further information see Table 1 and legend of Fig. 3.

The pyrolysate of this latter sample shows a trace typical of undegraded angiosperm wood. The $\delta^{13} \mathrm{C}$ value of sample $2 \mathrm{c}$ is closest to that of modern oak. Although natural heterogeneity could be of importance, the molecular data show that the more depleted value of sample 1c could be explained by the selective removal of the ${ }^{13} \mathrm{C}$ enriched polysaccharides. Thus for archaeological samples molecular data may help to explain variations in bulk values.

\subsection{Tertiary material}

Eight Tertiary specimens were studied revealing large variations in $\delta^{13} \mathrm{C}$ values of the bulk wood (Table 1). The three Antarctic Nothofagus specimens showed less depleted values $(-22.4 \%$ o to $-23.4 \%$ ) compared with the older Miocene brown coal-derived specimens $(-23.9 \%$ to $-26.0 \% 0$ ). As these latter specimens are more characteristic of the kind of organic wood remains 


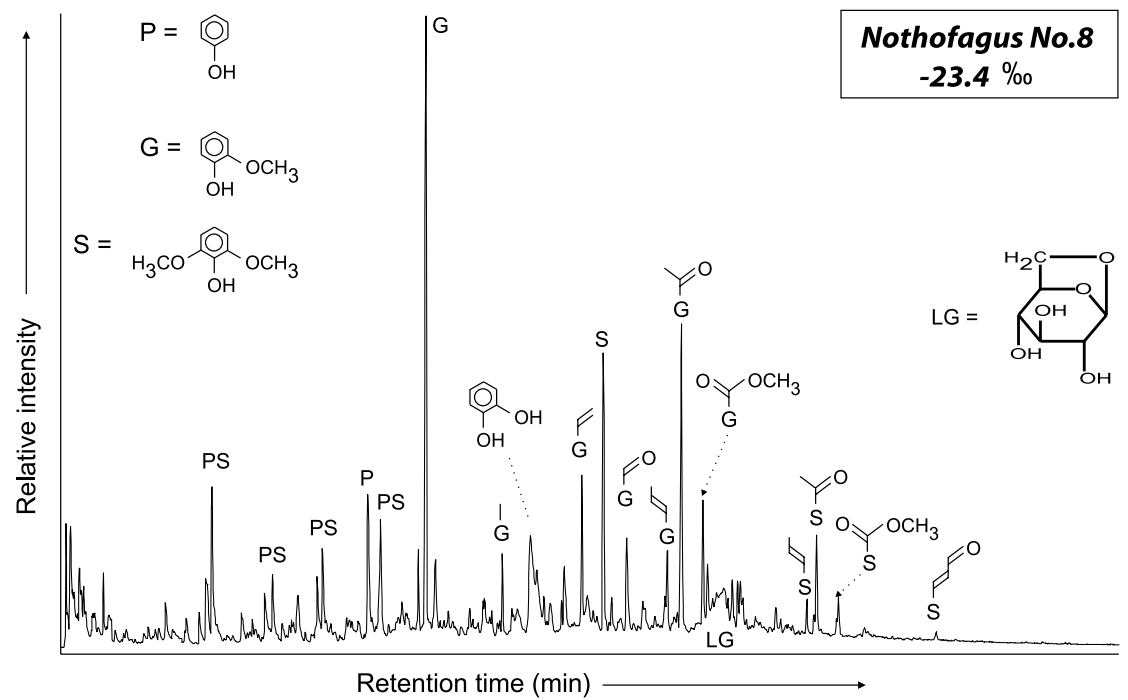

Fig. 5. Total ion current of on-line flash pyrolysate of Pliocene/Miocene mummified wood showing the distinct change in lignin pyrolysis products indicating changes in lignin composition. For further information see Table 1 and legend of Fig. 3.

found normally in the fossil record, these shall be discussed first.

In general, the three Miocene gymnosperm specimens are slightly less depleted than the two Miocene angiosperm specimens. This is in agreement with data from modern material (Stuiver and Braziunas, 1987) and other similarly preserved fossil wood specimens from the German Lower Rhine Embayment (Frielingsdorf, 1993; Lücke et al., 1999; Schleser et al., 1999). Whether these differences have purely physiological causes or are related to the different chemical composition of the lignin (i.e., the presence of one or two methoxy groups) in these two groups is not known. This off-set indicates the importance of using the same taxon, if possible, when interpreting palaeoenvironmental/palaeoclimatic conditions based on fossil wood.

As these isotope results indicate values seemingly useful for palaeoclimate interpretations, we wanted to determine whether the bulk values were affected by changes in the chemical composition. The pyrolysates of all three gymnosperm specimens were dominated by characteristic lignin markers (solely guaiacyl derivatives) with evidence of relatively little polysaccharides pyrolysis products (LG, Fig. 4A). These data clearly indicate that some chemical alteration has already taken place (cf. pyrolysates of modern conifer wood; Saiz-Jimenez et al., 1987; Kuroda and Yamaguchi, 1995). More importantly, however, the relative abundance of polysaccharide products was highest in the specimen with the least depleted value $(\mathrm{Az} 1 ;-23.9 \% 0)$ and lowest in specimen R2 (Table 1; $-24.9 \%$ ). The two angiosperm specimens also revealed clear evidence of lignin and polysaccharide pyrolysis markers; the specimen with the highest relative abundance of polysaccharide markers again yielded the least depleted $\delta^{13} \mathrm{C}$ value (Fig. 4B). These observations concerning the variation in amount of cellulose on isotope values of bulk fossil wood samples are fully in accordance with previous studies (Spiker and Hatcher, 1987; Schleser et al., 1999).

Apart from the removal of polysaccharides, the molecular data of the angiosperm specimens also showed changes in the lignin composition. Firstly, a relative decrease of 2,6-dimethoxyphenol moieties (S) was observed when compared with 2-methoxyphenol units $(\mathrm{G})$ (cf. Fig. 3B versus Fig. 4B). Pyrolysates of modern-day angiosperms generally show higher relative amounts of syringyl units (cf. Boon et al., 1989; van Bergen et al., 2000). The selective removal of the syringyl units is well known (e.g., van Bergen et al., 2000 and references cited therein) but whether this affects the iso- 
tope composition of the wood is as yet uncertain. Secondly, 1,2-benzenediols (C, 3C and 4C in Fig. 4) were detected revealing chemical alterations of the resistant lignin component. The primary chemical reaction involved in this latter alteration is demethylation of the methoxy group. As the carbon in the methoxy group is isotopically lighter than the total carbon of the aromatic ring (Galimov, 1985), this kind of chemical alteration of the lignin will affect ultimately the isotope value of bulk wood samples.

Further evidence of chemical alterations affecting bulk isotope data was gained from the mummified Nothofagus specimens from Antarctica. These three samples revealed relatively ${ }^{13} \mathrm{C}$ enriched $\delta^{13} \mathrm{C}$ values (Table 1). Since these samples are of a different age than the Miocene brown coal specimens the relatively heavy values could be construed as evidence of a distinct atmospheric $\mathrm{CO}_{2}$ composition at the time these plants grew. Alternatively, selective removal of the ${ }^{13} \mathrm{C}$ depleted lignin would account for these heavy values.

Upon pyrolysis, all three specimens yielded similar pyrolysates (Fig. 5) significantly different from other pyrolysis traces of fossil woods reported to date. The pyrolysates were dominated by the basic methoxyphenol derivatives, $\mathrm{G}$ and $\mathrm{S}$ (with no side-chain), and oxygenated methoxyphenols, eliminating selective removal of lignin as the sole cause for the heavy isotope values. Other prominent compounds included various non-characteristic polysaccharide products (PS), but the relatively low abundance of LG is noteworthy. These observations of the PS imply that although polysaccharides are still present, their original molecular composition has been altered, which in turn may have also affected their isotope composition. Significant in this respect is the recent study by Schleser et al. (1999) who showed that the isotope composition of cellulose became relatively enriched during artificial diagenesis and thus suggested that its isotope composition is not stable over (geological) time. This could also explain the general trend of apparently enriched $\delta^{13} \mathrm{C}$ values of cellulose reported in several older fossil woods (Spiker and Hatcher, 1987; Frielingsdorf, 1993; Lücke et al., 1999) being related to chemical alterations rather than to changes in atmospheric $\mathrm{CO}_{2}$ composition.

Although lignin is still present, several products such as 1,2-benzenediols and oxygenated methoxyphenols, as well as the distinct distribution of individual methoxyphenol derivatives, indicate chemical modifications to the core lignin moieties (i.e., increased cross-linking and/or oxidation of the lignin macro-structure; cf. Hatcher et al., 1989a,b; van Bergen et al., 1994a). These alterations are most probably caused by the mummification process. As mentioned above, demethylation of the lignin moieties would cause a shift to more ${ }^{13} \mathrm{C}$ enriched values but to what extent the oxygenation or the alteration, responsible for the different distribution pattern, affects the isotope composition is as yet unknown. Clearly, the distinct isotope values of these Antarctic wood specimens are related directly to their chemical composition. The main differences observed between the brown coal specimens and the mummified samples are believed to be related to the varying depositional environments. The material obtained from the brown coal showed higher quality molecular preservation and thus revealed more accurately their original carbon isotope composition.

\subsection{Older fossils}

A phenomenon recognised for most older fossil plant material is the apparent general ${ }^{13} \mathrm{C}$ enrichment over time (e.g., Gröcke, 1998). This observation also holds true for scant Mesozoic and $\mathrm{Pa}-$ laeozoic wood results published to date (e.g., Jones, 1994; Gröcke, 1998; Gröcke et al., 1999; approx. 5\%o enrichment). Our data from the two Cretaceous conifer specimens also show these distinct enriched values (approx. $-21.3 \%$ ), with no variation within and little variation between the two samples (Table 1).

Although various explanations have been proposed (Gröcke, 1998), one general assumption is that the fossil wood studied still comprises a macromolecule similar to the original ligno-cellulose, or a molecule which has undergone minor alterations such as the removal of the polysaccharide moieties. This assumption is certainly true for most Tertiary woods (see data above), but de- 


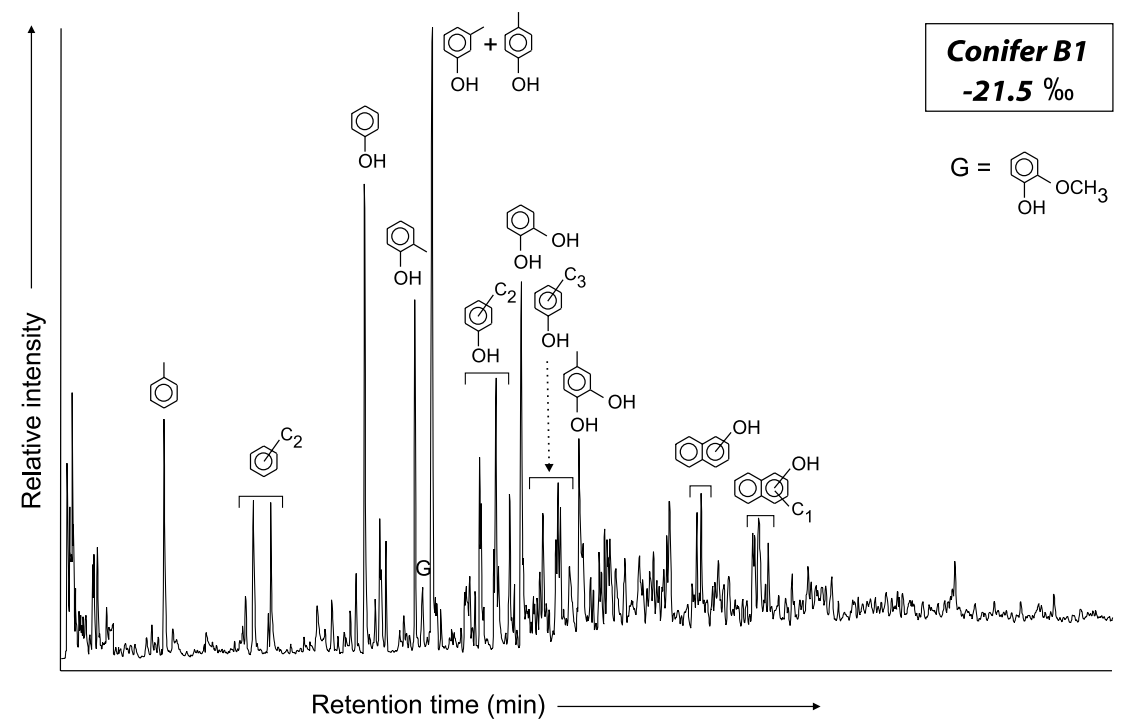

Fig. 6. Total ion current of on-line flash pyrolysate of Cretaceous wood revealing the absence of polysaccharides and the virtual lack of lignin. Most products can be ascribed to heavily transformed lignin. For further information see Table 1 and legend of Fig. 3.

tailed molecular data from Palaeozoic, Mesozoic and many Palaeogene wood specimens show rather different results. Although lignin is suggested to have been present in Palaeozoic plants (Niklas and Pratt, 1980; Logan and Thomas, 1987; Ewbank et al., 1996), to date very little unequivocal molecular evidence, i.e., the presence of characteristic 2-methoxyphenols, has been reported suggesting lignin in plant material older than the late Mesozoic and even then still only in very small amounts (Hayatsu et al., 1981; Hatcher and Lerch, 1991). Upon diagenesis lignin undergoes chemical alteration, initially leading to a macromolecule with mainly 1,2-benzenediol moieties, subsequently to a phenol dominated macromolecule and ultimately to a highly defunctionalised aromatic network (Hatcher and Clifford, 1997 and references cited therein). However, the presence of phenols and aromatics in older plant fossils does not necessary indicate a lignin origin (cf. van Bergen et al., 1995b; Abbott et al., 1998).

Surprisingly, detailed molecular analyses are rarely considered when $\delta^{13} \mathrm{C}$ values of older wood specimens, and fossil plants in general, are discussed. The pyrolysates of the Cretaceous coni- fer samples analysed yielded the same products. The pyrolysates were dominated by (alkyl)phenols, 1,2-benzenediols and alkylated benzenes (Fig. 6). No polysaccharide pyrolysis products and only one true lignin marker, 2-methoxyphenol, were detected. The dominant pyrolysis products are known to be released from diagenetically altered wood specimens (Hatcher et al., 1989a,b; Hatcher and Lerch, 1991) clearly indicating that the macromolecular structure in these Cretaceous woods had undergone major chemical alterations. This is an essential observation because very little is known about the true isotope effects occurring during these lignin alteration processes, apart from the fact that the formation of the 1,2-benzenediol network will lead to ${ }^{13} \mathrm{C}$ enriched values (Schleser et al., 1999). Possibly the increased cross-linking, loss of the $\mathrm{C}_{3}$ alkyl side-chain and the bond-breaking and bond-making that occur during these chemical changes (Hatcher and Clifford, 1997) cause these dramatic shifts in the isotope composition. Thus the isotope signal of these older fossil wood specimens is strongly dependent on the chemical changes that have occurred. Interestingly, a recent study of Cretaceous woods from Australia showed that some of the isotope 


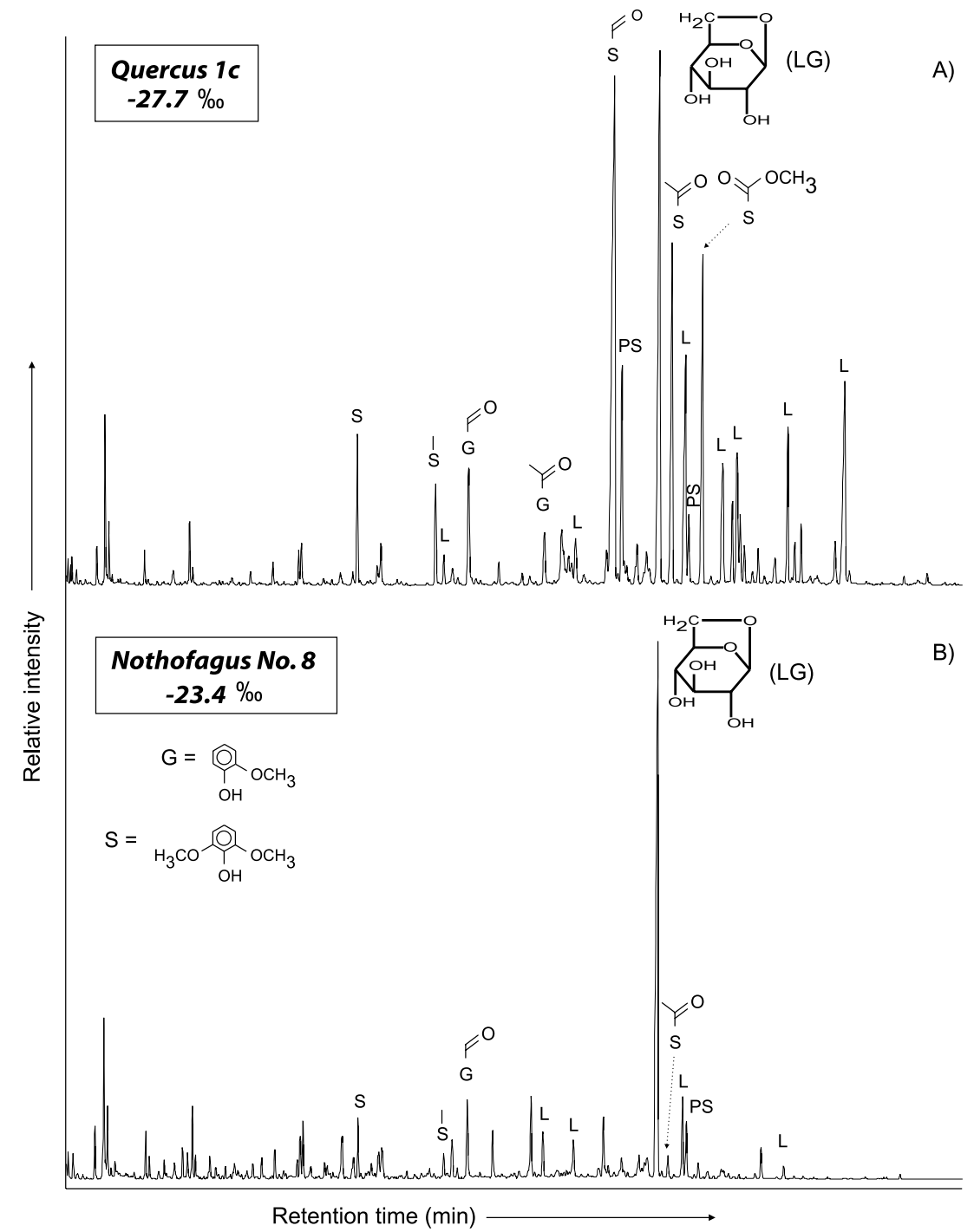

Fig. 7. Gas chromatograms of off-line pyrolysates of an archaeological (A) and fossil (B) wood specimen. Pyrolysis products are analysed as their trimethylsilylated derivatives. Traces show the presence of both polysaccharide and lignin derived products. For further information see Table 1 and legend of Fig. 3.

variation observed was related to lithology (Gröcke, 1998), a factor known to affect the lignin chemistry (van Bergen et al., 1994b).

\subsection{Directives to overcome problems associated with chemical variation}

Despite these chemically induced variations, a recent study of bulk $\delta^{13} \mathrm{C}$ values of Cretaceous wood from the Isle of Wight, UK, showed large variations (approx. $-30 \%$ to $-18 \%$ ) that could not be explained solely by lithological variations and are possibly related to, amongst others, changes in climatic factors (Gröcke et al., 1999). Palaeoclimatic information can be obtained from bulk fossil wood when a number of factors are taken into consideration viz., the use of (i) a single taxon and (ii) fossil specimens that have under- 
gone identical chemical alterations, for example gelified wood ('jet') (Hesselbo et al., 2000), both of which will reduce intrinsic chemical variations.

An alternative approach, which may overcome the problems pertaining to the use of bulk samples from fossils still containing identifiable remnants of ligno-cellulose, is the measuring of stable carbon isotope values of polysaccharide and/or lignin markers released by pyrolysis. Chemically released cellulose and lignin fractions have been obtained before (e.g., Wilson and Grinsted, 1977; Spiker and Hatcher, 1987) but could never be studied simultaneously. Moreover, it is not known whether carbon isotope fractionations are induced during their release or to what extent the molecular structure is altered (Spiker and Hatcher, 1987; Bates and Spiker, 1992). With our new approach, wood samples are pyrolysed off-line $\left(400^{\circ} \mathrm{C}, 1 \mathrm{~h}\right)$ which allows the released products to be collected and analysed separately. Fig. 7 shows examples of off-line pyrolysates of two specimens also studied using on-line pyrolysis (cf. Figs. 3A and 5). The differences in products released relate purely to the different pyrolysis methods, although the significant quantity of LG in the Nothofagus sample compared with the on-line data (Fig. 5) is noteworthy. Both pyrolysates show polysaccharide (PS) and lignin (L) derived products, which can be studied directly by compound-specific stable carbon isotope analyses and as such provide detailed information on both moieties in ligno-cellulose. Furthermore, by targeting only specific lignin markers reflecting the lignin core we can reduce variation resulting from changes in the macromolecular lignin structure. Ongoing research is using this approach to gain further detailed insights into changes in stable carbon isotopes in fossil wood over time and assess these in terms of changes in palaeoenvironments and palaeoclimate.

\section{Conclusions}

Detailed molecular and stable carbon isotope investigations of archaeological and fossil wood specimens revealed large differences in their isotope composition. Although natural heterogeneity is a possible source for some of this variation, most of the isotope differences in the archaeological and Tertiary specimens can be related to either the amount of polysaccharides present, or the degree of lignin alteration. In case of the Cretaceous specimens, the molecular data revealed only heavily modified lignin, with virtually no intact lignin building blocks (2-methoxyphenols) being preserved, and no evidence of polysaccharides. This dramatic alteration of the chemical composition is suggested to be one of the main causes for the distinct ${ }^{13} \mathrm{C}$ enriched values of these specimens. Overall, these data clearly show the importance of combining detailed molecular information on the individual wood components with stable carbon isotope data in order to help further our understanding in determining how stable carbon isotopes from wood can be used for palaeoenvironmental and palaeoclimatic interpretations.

\section{Acknowledgements}

We thank the UK-Dutch Joint Scientific Research Project JRP472 for financial support during which most of the initial work was undertaken. Dr U. Sass-Klaassen provided the modern oak wood sample, Dr I. Figueiral provided the Miocene specimens, Dr L. Whitcombe and the divers of the British Sub-Aqua club (No. 551) provided the archaeological material, Dr J. Francis provided the Sirius Nothofagus material and Dr D. Cantrill provided the Cretaceous conifer specimens. The use of on-line pyrolysis facilities at the Department of Marine Biogeochemistry and Toxicology at NIOZ is gratefully acknowledged. Wim Pool and Mark van Alphen are thanked for help with the mass spectrometry analyses. Desire Smith is thanked for help with the bulk stable carbon isotope analyses.

\section{References}

Abbott, G.D., Ewbank, G., Edwards, D., Wang, G.-Y., 1998. Molecular characterisation of some enigmatic Lower Devonian land plants. Geochim. Cosmochim. Acta 62, 1407-1418. 
Arens, N.C., Jahren, A.H., 2000. Carbon isotope excursion in atmospheric $\mathrm{CO}_{2}$ at the Cretaceous-Tertiary boundary: Evidence from terrestrial sediments. Palaios 15, 314-322.

Arens, N.C., Jahren, A.H., Amundson, R., 2000. Can C3 plants faithfully record the carbon isotope composition of the atmospheric carbon dioxide? Paleobiology 26, 137-164.

Bates, A.L., Spiker, E.C., 1992. Chemical changes and carbon isotope variations in a cross-section of a large Miocene gymnospermous log. Chem. Geol. 101, 247-254.

Beerling, D.J., Mattey, D.P., Chaloner, W.G., 1993. Shifts in the $\delta^{13} \mathrm{C}$ composition of Salix herbaceae L. leaves in response to spatial and temporal gradients of atmospheric $\mathrm{CO}_{2}$ concentration. Proc. R. Soc. London B 253, 53-60.

Beerling, D.J., Woodward, F.I., 1996. Stomatal density responses to global environmental change. Adv. Bioclimatol. 4, 171-221.

Benner, R., Fogel, M.L., Sprague, E.K., Hodson, R.E., 1987. Depletion of ${ }^{13} \mathrm{C}$ in lignin and its implications for stable carbon isotope studies. Nature 329, 708-710.

Bert, D., Leavitt, S.W., Dupouey, J-L., 1997. Variations of wood $\delta^{13} \mathrm{C}$ and water-use efficiency of Abies alba during the last century. Ecology 78, 1588-1596.

Bocherens, H., Friis, E.M., Mariotti, A., Pederson, K.R., 1993. Carbon isotope abundances in Mesozoic and Cenozoic fossil plants: Palaeoecological implications. Lethaia 26, 347-358.

Boon, J.J., Stout, S.A., Genuit, W., Spackman, W., 1989. Molecular palaeobotany of Nyssa endocarps. Acta Bot. Neerl. 38, 391-404.

Carlquist, S., 1987. Pliocene Nothofagus wood from the Transantarctic Mountains. Aliso 11, 571-583.

Craig, H., 1954. Carbon-13 variations in Sequoia rings and the atmosphere. Science 119, 141-143.

Degens, E.T., 1969. Biochemistry of stable carbon isotopes. In: Eglinton, G., Murphy, M.T.J. (Eds.), Organic Geochemistry, Methods and Results. Longman, New York, pp. 304 329.

Edwards, T.W.D., Luckman, B.H., 1996. Isotope dendroclimatology studies in the Canadian Rockies: some preliminary results. In: Dean, J.S., Meko, D.M., Swetman, T.W. (Eds.), Tree Rings, Environment and Humanity. Radiocarbon, pp. 585-596.

Ewbank, G., Edwards, D., Abbott, G.D., 1996. Chemical characterization of Lower Devonian vascular plants. Organic Geochemistry 25, 461-473.

Farmer, J.G., 1979. Problems in interpreting tree-ring $\delta^{13} \mathrm{C}$ records. Nature 279, 229-231.

Farmer, J.G., Baxter, M.S., 1974. Atmospheric carbon dioxide levels as indicated by the stable isotope record in wood. Nature 247, 273-275.

Farquhar, G.D., O'Leary, M., Berry, J.A., 1982. On the relationship between carbon isotope discrimination and the intercellular carbon dioxide concentration in leaves. Aust. J. Plant Physiol. 9, 121-137.

Farquhar, G.D., Ehleringer, J.R., Hubick, K.T., 1989. Carbon isotope discrimination and photosynthesis. Annu. Rev. Plant Physiol. Plant Mol. Biol. 40, 503-537.

Figueiral, I., Mosbrugger, V., Rowe, N.P., Ashraf, A.R.,
Utescher, T., Jones, T.P., 1999. The Miocene-peat forming vegetation of northwestern Germany: an analysis of wood remains and comparison with previous palaynological interpretations. Rev. Palaeobot. Palynol. 104, 239-266.

Francey, R.J., Farquhar, G.D., 1982. An explanation of ${ }^{13} \mathrm{Cl}$ ${ }^{12} \mathrm{C}$ variations in tree rings. Nature 297, 28-31.

Frielingsdorf, J., 1993. Kohlenstoff-isotopendaten von Tertiären Hölzern der Niederrheinischen Bucht. Isot.prax. Environ. Health Stud. 29, 27-34.

Galimov, E.M., 1985. The Biological Fractionation of Isotopes. Academic Press, Orlando, FL.

Gröcke, D.R., 1998. Carbon-isotope analyses of fossil plants as a chemostratigraphic and palaeoenvironmental tool. Lethaia 31, 1-13.

Gröcke, D.R., Hesselbo, S.P., Jenkyns, H.C., 1999. Carbonisotope composition of Lower Cretaceous fossil wood: Ocean-atmosphere chemistry and relation to sea level change. Geology 27, 155-158.

Hatcher, P.G., Lerch, H.E. III, 1991. Survival of lignin-derived structural units in ancient coalified wood samples. In: Schobert, H.H., Bartle, K.D., Lynch, L.J. (Eds.), Coal Science II. ACS symposium series 461, Americal Chemical Society, Washington, DC, pp. 9-19.

Hatcher, P.G., Clifford, D.J., 1997. The organic geochemistry of coal: from plant materials to coal. Org. Geochem. 27, 251-274.

Hatcher, P.G., Lerch, H.E., III, Verheyen, T.V., 1989a. Organic geochemical studies of the transformation of gymnospermous xylem during peatification and coalification to subbituminous coal. Int. J. Coal Geol. 13, 65-97.

Hatcher, P.G., Wilson, M.A., Vassallo, A.M., Lerch, H.E., III, 1989b. Studies of angiospermous wood in Australian coal by nuclear magnetic resonance and analytical pyrolysis; new insights into the early coalification process. Int. J. Coal Geol. 13, 99-126.

Hayatsu, R., Winans, R.E., McBeth, R.L., Scott, R.G., More, L.P., 1981. In: Gorbaty, M.L., Ouchi, K. (Eds.), Coal Structure. Advances in Chemistry Series 192, American Chemical Society, Washington, DC, 133-149.

Hedges, J.I., Cowie, G.L., Ertel, J.R., Barbour, R.J., Hatcher, P.G., 1985. Degradation of carbohydrates and lignins in buried woods. Geochim. Cosmochim. Acta 49, 701-711.

Hesselbo, S.P., Gröcke, D.R., Jenkyns, H.C., Bjerrum, C.J., Farrimond, P., Morgans Bell, H.S., Green, O.R., 2000. Massive dissociation of gas hydrate during a Jurassic oceanic anoxic event. Nature 406, 392-395.

Huang, Y., Lockheart, M.J., Collister, J.W., Eglinton, G., 1995. Molecular and isotopic biogeochemistry of the Miocene Clarkia Formation: hydrocarbons and alcohols. Org. Geochem. 23, 785-801.

Huang, Y., Lockheart, M.J., Logan, G.A., Eglinton, G., 1996. Isotope and molecular evidence for the diverse origins of carboxylic acids in leaf fossils and sediments from the Miocene Clarkia deposit, Idaho, USA. Org. Geochem. 24, 289 299.

Jones, T.P., 1994. ${ }^{13} \mathrm{C}$ enriched Lower Carboniferous fossil plants from Donegal, Ireland: carbon isotope constraints 
on taphonomy, diagenesis and palaeoenvrionment. Rev. Palaeobot. Palynol. 81, 53-64.

Jones, T.P., Rowe, N.P. (Eds.), 1999. Fossil Plants and Spores: Modern Techniques. Geological Society, London.

Kuroda, K.-I., Yamaguchi, A., 1995. Classification of Japanese solfwood species by pyrolysis-gas chromatography. J. Anal. Appl. Pyrolysis 33, 51-59.

Kürschner, W.M., van der Burgh, J., Visscher, H., Dilcher, D.L., 1996. Fossil oak leaves as biosensors of Late Neogene to early Pleistocene palaeoatmospheric $\mathrm{CO}_{2}$ concentrations. Mar. Micropalaeontol. 27, 299-312.

Leavitt, S.W., Long, A., 1982. Evidence for ${ }^{13} \mathrm{C} /{ }^{12} \mathrm{C}$ fractionation between tree leaves and wood. Nature 298, 742-744.

Leavitt, S.W., Long, A., 1983. An atmospheric ${ }^{13} \mathrm{C} /{ }^{12} \mathrm{C}$ reconstruction generated through removal of climate effects from tree-ring ${ }^{13} \mathrm{C} /{ }^{12} \mathrm{C}$ measurements. Tellus 35B, 92-102.

Leavitt, S.W., Long, A., 1986. Stable-carbon isotope variability in tree foliage and wood. Ecology 67, 1002-1010.

Leavitt, S.W., Long, A., 1991. Seasonal stable-carbon isotope variability in tree rings: possible palaeoenvironmental signals. Chem. Geol. (Isot. Geosci. Sect.) 87, 59-70.

Lewis, N.G., Yamamoto, E., 1990. Lignin: occurrence, biogenesis and biodegradation. Annu. Rev. Plant Physiol. Plant Mol. Biol. 41, 455-496.

Lipp, J., Trimborn, P., Graf, W., Edwards, T., Becker, B., 1996. Climate signals in a ${ }^{2} \mathrm{H}$ and ${ }^{13} \mathrm{C}$ chronology (18821989) from tree rings of spruce (Picea abies L.), Schussbach forest, Germany. In: Dean, J.S., Meko, D.M., Swetman, T.W. (Eds.), Tree Rings, Environment and Humanity. Radiocarbon, pp. 603-610.

Lockheart, M.J., 1997. Isotope Compositions and Distributions of Individual Compounds as Indicators for Environmental Conditions. Ph.D. Thesis, University of Bristol, Bristol.

Lockheart, M.J., van Bergen, P.F., Evershed, R.P., 1997. Variations in the stable carbon isotope compositions of individual lipids observed in the leaves of modern angiosperms: implications for the study of higher land plant derived sedimentary organic matter. Org. Geochem. 26, 137-153.

Lockheart, M.J., Poole, I., van Bergen, P.F., Evershed, R.P., 1998. Leaf carbon isotope compositions and stomatal characters: important considerations for palaeoclimate reconstructions. Org. Geochem. 29, 1003-1008.

Logan, K.J., Thomas, B.A., 1987. The distribution of lignin derivatives in fossil plants. New Phytol. 105, 157-173.

Lücke, A., Helle, G., Schleser, G.H., Figueiral, I., Mosbrugger, V., Jones, T.P., Rowe, N.P., 1999. Environmental history of the German Lower Rhine Embayment during the Middle Miocene as reflected by carbon isotopes in brown coal. Palaeogeogr. Palaeoclimatol. Palaeoecol. 154, 339-352.

Mazany, T., Lerman, J.C., Long, A., 1980. Carbon-13 in tree ring cellulose as an indicator of past climates. Nature 287, 432-435.

Mosbrugger, V., 1999. The nearest living relative method. In: Jones, T.P., Rowe, N.P. (Eds.), Fossil Plants and Spores: Modern Techniques. Geological Society, London, pp. 261265.
Nguyen Tu, T.T., Bocherens, H., Mariotti, A., Baudin, F., Pons, D., Broutin, J., Derenne, S., Largeau, C., 1999. Ecological distribution of Cenomanian terrestrial plants based on ${ }^{13} \mathrm{C} /{ }^{12} \mathrm{C}$ ratios. Palaeogeogr. Palaeoclimatol. Palaeoecol. 145, 79-93.

Niklas, K.J., Pratt, L.M., 1980. Evidence for lignin-like constituents in early Silurian (Llandoverian) plant fossils. Science 209, 396-397.

Ogle, N., McCormac, F.G., 1996. Further high-resolution $\delta^{13} \mathrm{C}$ measurements of oak reveal a spring depletion. In: Dean, J.S., Meko, D.M., Swetman, T.W. (Eds.), Tree Rings, Environment and Humanity. Radiocarbon, pp. 611-615.

O'Leary, M., 1981. Carbon isotope fractionation in plants. Phytochemistry 20, 553-567.

Poole, I., Weyers, J.D.B., Lawson, T., Raven, J., 1996. Variations in stomatal density and index: implications for palaeoclimatic reconstructions. Plant Cell Environ. 19, 705-712.

Pouwels, A.D., Tom, A., Eijkel, G.B., Boon, J.J., 1987. Characterisation of beech wood and its holocellulose and xylan fractions by pyrolysis gas chromatography mass spectrometry. J. Anal. Appl. Pyrolysis 11, 417-437.

Pouwels, A.D., Eijkel, G.B., Boon, J.J., 1989. Curie point pyrolysis capillary gas chromatography high resolution mass spectrometry of microcrystalline cellulose. J. Anal. Appl. Pyrolysis 14, 237-280.

Ralph, J., Hatfield, R.D., 1991. Pyrolysis-GC-MS characterisation of forage materials. J. Agric. Food Chem. 39, 14261437.

Robertson, I., Pollard, A.M., Heaton, T.H.E., Pilcher, J.R., 1996. Seasonal changes in the isotopic composition of oak cellulose. In: Dean, J.S., Meko, D.M., Swetman, T.W. (Eds.), Tree Rings, Environment and Humanity. Radiocarbon, pp. 617-628.

Saiz-Jimenez, C., de Leeuw, J.W., 1986. Lignin pyrolysis products: Their structures and their significance as biomarkers. Org. Geochem. 10, 869-876.

Saiz-Jimenez, C., Boon, J.J., Hedges, J.J., Hessels, J.K.C., de Leeuw, J.W., 1987. Chemical characterisation of recent and buried wood by analytical pyrolysis: comparison of pyrolysis data with ${ }^{13} \mathrm{C}$ NMR and wet chemical data. J. Anal. Appl. Pyrolysis 11, 437-450.

Sarkanen, K.V., Ludwig, C.H. (Eds.), 1971. Lignins. Occurrence, Formation, Structure and Reactions. Wiley-Interscience, New York.

Schleser, G.H., 1992. $\delta^{13} \mathrm{C}$ pattern in forest tree as an indicator of carbon transfer in trees. Ecology 73, 1922-1925.

Schleser, G.H., Frielingsdorf, J., Blair, A., 1999. Carbon isotope behaviour in wood and cellulose during artificial aging. Chem. Geol. 158, 121-130.

Spiker, E.C., Hatcher, P.G., 1987. The effects of early diagenesis on the chemical and stable carbon isotopic composition of wood. Geochim. Cosmochim. Acta 51, 1385-1391.

Stankiewicz, B.A., Mastalerz, M., Kruge, M.A., van Bergen, P.F., Sadowska, A., 1997. A comparative study of modern and fossil cone scales and seeds of conifers: a geochemical approach. New Phytol. 135, 375-393.

Stankiewicz, B.A., van Bergen, P.F., Smith, M.B., Carter, J.F., 
Briggs, D.E.G., Evershed, R.P., 1998. Comparison of analytical performance of filament and Curie-point pyrolysis devices. J. Anal. Appl. Pyrolysis 45, 133-151.

Stuiver, M., Braziunas, T.F., 1987. Tree cellulose ${ }^{13} \mathrm{C} /{ }^{12} \mathrm{C}$ isotope ratios and climate change. Nature 328, 58-60.

Switsur, V.R., Waterhouse, J.S., Field, E.M., Carter, A.H.C., 1996. Climatic signals from stable isotopes in oak tree rings from East Anglia, Great Britain. In: Dean, J.S., Meko, D.M., Swetman, T.W. (Eds.), Tree Rings, Environment and Humanity. Radiocarbon, pp. 637-645.

Tans, P.P., Mook, W.G., 1980. Past atmospheric $\mathrm{CO}_{2}$ levels and the ${ }^{13} \mathrm{C} /{ }^{12} \mathrm{C}$ ratios in tree rings. Tellus 32, 268-283.

van Bergen, P.F., 1999. Pyrolysis and chemolysis of fossil plant remains: applications to palaeobotany. In: Jones, T.P., Rowe, N.P. (Eds.), Fossil Plants and Spores: Modern Techniques. Geological Society, London, pp. 143-148.

van Bergen, P.F., Goñi, M., Collinson, M.E., Barrie, P.J., Sinninghe Damsté, J.S., de Leeuw, J.W., 1994a. Chemical and microscopic characterisation of outer seed coats of fossil and extant water plants. Geochim. Cosmochim. Acta 58, 3823-3844.

van Bergen, P.F., Collinson, M.E., Hatcher, P.G., de Leeuw, J.W., 1994b. Lithological control on the state of preservation of fossil seed coats of water plants. Org. Geochem. 22, 683-702.

van Bergen, P.F., Collinson, M.E., Briggs, D.E.G., de Leeuw, J.W., Scott, A.C., Evershed, R.P., Finch, P., 1995a. Resistant biomacromolecules in the fossil record. Acta Bot. Neerl. 44, 319-342.

van Bergen, P.F., Collinson, M.E., Scott, A.C., de Leeuw, J.W., 1995. Unusual Resin Chemistry From Upper Carbon- iferous Pteridosperm Resin Rodlets. In: Anderson, K.B., Crelling, J.C. (Eds.), Amber, Resinite and Fossil Resin. ACS Symposium Series 617, American Chemical Society, Washington, DC, pp. 149-169.

van Bergen, P.F., Collinson, M.E., de Leeuw, J.W., 1996. Characterisation of the insoluble constituents of propagule walls of fossil and extant water lilies; implications for the fossil record. Anc. Biomol. 1, 55-81.

van Bergen, P.F., Poole, I., Ogilvie, T.M.A., Caple, C., Evershed, R.P., 2000. Evidence for demethylation of syringyl moieties in archaeological wood using pyrolysis/gas chromatography/mass spectrometry. Rapid Commun. Mass Spectrom. 14, 71-79.

van der Burgh, J., Visscher, H., Dilcher, D.L., Kürschner, W.M., 1993. Atmospheric signatures in Neogene fossil leaves. Science 260, 1788-1790.

Wheeler, E.A., Baas, P., 1993. The potentials and limitations of dicotyledonous wood anatomy for climatic reconstructions. Paleobiology 19, 487-498.

Whitcombe, L.J., 1995. Sediment Transport Processes, with Particular Reference to Hayling Island. Ph.D. Thesis, University of Southampton, Southampton.

Wiemann, M.C., Wheeler, E.A., Manchester, S.R., Portier, K.M., 1998. Dicotyledonous wood anatomical characters as predictors of climate. Palaeogeogr. Palaeoclimatol. Palaeoecol. 139, 83-100.

Wiemann, M.C., Manchester, S.R., Wheeler, E.A., 1999. Paleotemperature estimation from dicotyledonous wood anatomical characters. Palaios 14, 459-474.

Wilson, A.T., Grinsted, M.J., 1977. ${ }^{12} \mathrm{C} /{ }^{13} \mathrm{C}$ in cellulose and lignin as palaeothermometres. Nature 265, 133-135. 